\title{
Efektivitas Krim Papain Kasar Getah Buah Pepaya (Carica Papaya.L) yang Diolah dengan Metode Freeze Drying terhadap Penyembuhan Penebalan Kulit (Callus)
}

\section{(The Effectiveness of Papain Rough Papaya Crude Cream (Carica Papaya.L) Processed with Freeze Drying Method against Healing Skin Thickening (Callus))}

\author{
Deni Anggraini ${ }^{1}$, Emma Susanti $^{1}$, Norman Saputra ${ }^{1}$ \\ ${ }^{1}$ Sekolah Tinggi Ilmu Farmasi Riau, Jl kamboja Simpang Baru Panam Pekanbaru kode pos 28293 \\ Email : anggrainideni152@gmail.com
}

\begin{abstract}
Article Info:

Received: 14 January 2020

Accepted: 26 March 2020

DOI:

10.33772/pharmauho.v6i1.

10407

Research on the effectiveness of crude papain cream papaya (Carica papaya L) has been conducted which is processed using the freeze drying method and its relationship to the effectiveness of healing skin thickening (Callus). This study aims to determine the effectiveness of crude papain proteolytic in curing skin thickening which is processed by the freeze drying method. The formula is made by varying the concentration of papain $10 \%, 15 \%$, and $20 \%$ by using type w/o cream. The evaluation of cream preparations includes organoleptic, homogeneity, $\mathrm{pH}$, temperature stability, washability of the cream, spreadability and skin irritation test. The results showed papain can be formulated into a cream to cure skin thickening. The results of the reduction the average diameter of skin thickening caused by positive control of salicylic acid cream concentration of $20 \%$ is $1.35 \mathrm{~cm}$, not as effective as the reduction in the average diameter of skin thickening caused by papain cream concentration of $20 \%$
\end{abstract}

Keywords : Papain, callus, freeze drying, cream

\begin{abstract}
Abstrak
Telah dilakukan penelitian uji efektivitas krim papain kasar getah buah pepaya (Carica papaya L) yang diolah dengan metode freeze drying dan hubunganya terhadap efektivitas penyembuhan penebalan kulit (Callus). Penelitian ini bertujuan untuk mengetahui efektivitas proteolitik papain kasar dalam penyembuhan penebalan kulit yang diolah dengan metode freeze drying. Formula dibuat dengan memvariasikan konsentrasi papain 10\%, 15\%, dan 20\% dengan menggunakan krim tipe A/M. Evaluasi sediaan krim yang dilakukan meliputi organoleptis, homogenitas, $\mathrm{pH}$, stabilitas suhu, daya tercuci krim, daya menyebar dan uji iritasi kulit. Hasil penelitian menunjukkan papain dapat diformulasikan menjadi bentuk krim untuk penyembuhan penebalan kulit. Hasil pengurangan diameter rata-rata penebalan kulit yang diakibatkan oleh kontrol positif krim asam salisilat konsetrasi $20 \%$ yaitu $1,35 \mathrm{~cm}$, belum seefektif pengurangan diameter rata-rata penebalan kulit yang diakibatkan oleh krim papain konsentrasi $20 \%$.
\end{abstract}

Kata kunci: Papain, callus, freeze drying, krim

\section{Pendahuluan}

Pepaya (Carica papaya L) merupakan salah satu buah yang telah dikenal luas di Indonesia. Selain buah, bagian tanaman pepaya lainnya dapat dimanfaatkan untuk berbagai keperluan mulai sebagai bahan makanan dan minuman, obat tradisional, industri penyamakan kulit, kosmetik, dan sebagainya.
Salah satu substansi dari buah pepaya Substansi lain dari buah pepaya yang banyak dimanfaatkan dalam dunia industri adalah papain yang dapat dihasilkan dari buah, batang, ataupun daun pepaya. Papain merupakan salah satu enzim proteolitik yang paling banyak digunakan dalam industri. Aplikasinya cukup luas, mulai dari bahan pelunak daging hingga berbagai 
industri pangan, minuman, farmasi, detergent, kulit, wool, kosmetika, dan industri biologi lainnya [1].

Papain adalah enzim protease yang diisolasi dari lateks pepaya. Papain diperoleh dengan menoreh pepaya muda dan kemudian mengumpulkan dan mengeringkan lateks yang mengalir dari torehan pisau. Sebagai enzim proteolitik, papain sangat penting dalam proses biologis semua organisme hidup. Papain menunjukkan efektivitas proteolitik yang luas terhadap protein, rantai pendek peptida, ester asam amino dan amida dan juga diterapkan secara luas di bidang makanan dan obat-obatan. [2]. Enzim papain memiliki efektivitas menghidrolisis ikatan peptida menjadi molekul yang lebih sederhana yaitu asam amino. Hal ini yang dimanfaatkan dalam mengatasi penebalan kulit (Callus) [3].

Palmoplantar keratoderma adalah gangguan di mana kulit telapak tangan dan telapak kaki menjadi abnormal atau terjadi penebalan kulit (callus). Penyebabnya adalah protein abnormal di lapisan permukaan kulit (epidermis). Biasanya kulit tampak merah dan bersisik, atau keras dan kekuningan. Pada beberapa jenis keratoderm mempengaruhi seluruh permukaan telapak tangan dan telapak kaki, selain itu ada juga bergaris-garis atau seperti jagung (clavus) [4].

Pada penelitian terdahulu telah dilakukan pengujian karakterisasi papain kasar yang diperoleh dengan teknik pengering beku (freeze drying). Hasil yang didapat adalah aktifitas proteolitik papain kasar yang diperoleh dengan teknik pengering beku lebih baik dibanding dengan pengeringan oven vakum dan oven biasa [5]. Pada penelitian ini dilakukan pengujian efektivitas papain kasar yang dibuat dengan metode freeze drying dalam bentuk sediaan krim, untuk proses penyembuhan penebalan kulit (callus). Tujuan penelitian ini adalah melihat efektivitas krim papain kasar getah buah pepaya yang diperoleh dengan metode freeze drying dan melihat pengaruh variasi konsentrasi krim papain kasar terhadap penyembuhan callus.

\section{Metode}

\subsection{Alat dan Bahan}

Alat yang digunakan dalam penelitian ini adalah: freeze drying ( Christ ${ }^{\circledR}$ ), waterbath, wadah stainles steel, pisau, serbet kain, gelas piala, gelas ukur, erlemeyer, buret, labu ukur, pipet tetes, cawan penguap, kaca arloji, lumpang dan alu, pot plastik, oven, pH meter, timbangan digital (Shimadzu ${ }^{\circledR}$ ) dan jangka sorong. Bahan yang digunakan yaitu ; papain kasar getah buah pepaya, paraffin cair, trietanolamin, adeps lanae, gliserin, natrium metabisulfit, nipagin, nipasol, metilen biru, aquadest, asam stearat, cera alba, cetaceum, asam salisilat . Panelis 11 orang sukarelawan yang mengalami penebalan pada kulit (Callus).

\subsection{Pengolahan Papain kasar Getah Buah Pepaya}

Getah buah pepaya varietas unggul diolah menjadi papain kasar (crude papain) dengan cara dicampur larutan natrium metabisulfit 2,8\% sebanyak 4 kali jumlah getah, lalu diaduk merata dengan alat pengaduk (blender). Campuran ini membentuk emulsi getah berwarna putih susu agak kental, selanjutnya emulsi getah dibekukan dengan freezer. Setelah beku dimasukkan ke dalam pengering beku. Setelah kering getah diambil lalu digerus dan diayak dengan ayakan mesh 45. Papain kasar yang diperoleh dilakukan pemeriksaan meliputi organoleptis, dan kelarutan dalam air [6].

\subsection{Pembuatan Krim Papain}

Pembuatan krim diawalli dengan melebur fase minyak seperti parafin cair, asam stearat, cetaceum dan cera alba dalam cawan penguap di atas waterbath. Larutkan fase air dengan cara mencampur trietanolamin, nipagin dan nipasol dalam cawan penguap kemudian dipanaskan di atas penangas air sampai mencair. Campur fase minyak dan fase air dalam lumpang panas dan digerus sampai terbentuk massa krim yang homogen. Gliserin yang sudah ditambahkan air sama banyak dimasukkan ke massa krim yang sudah jadi dan digerus homogen.

Tabel 1. Formula Basis Krim Tipe A/M

\begin{tabular}{lc}
\hline \multicolumn{1}{c}{ Bahan } & Jumlah (\%) \\
\hline Asam stearate & 14,5 \\
Cera Alba & 2,5 \\
Cetaceum & 6,5 \\
Parafin cair & 25 \\
Gliserin & 1 \\
Trietanolamin & 1 \\
Nipagin & 0,1 \\
Nipasol & 0,05 \\
Aquadest & Ad 100 \\
& \\
\hline
\end{tabular}


Tabel 2. Formula Krim Papain

\begin{tabular}{cccc}
\hline Bahan & $\begin{array}{c}\text { Formula } \\
\text { I (\%) }\end{array}$ & $\begin{array}{c}\text { Formula } \\
\text { II (\%) }\end{array}$ & $\begin{array}{c}\text { Formula } \\
\text { III (\%) }\end{array}$ \\
\hline Papain Kasar & 10 & 15 & 20 \\
Basis krim ad & 100 & 100 & 100 \\
\hline
\end{tabular}

Timbang papain kasar sebanyak $10 \mathrm{~g}, 15 \mathrm{~g}$ dan $20 \mathrm{~g}$, gerus bersama basis krim sedikit demi sedikit sampai diperoleh krim papain sebanyak $100 \mathrm{~g}$. Krim disimpan dalam wadah bermulut lebar. Krim papain yang telah jadi dilakukan beberapa evaluasi meliputi evaluasi organoleptis, $\mathrm{pH}$, uji daya tercuci, uji iritasi, stabilitas, dan uji daya menyebar.

\subsection{Uji efektivitas Krim Papain Kasar Getah Buah Pepaya}

Pengujian dilakukan terhadap 11 orang sukarelawan atau panelis, 9 panelis untuk masingmasing formula, 1 panelis kontrol positif (asam salisilat 20\%) dan 1 panelis kontrol negatif (basis krim). Panelis dipilih yaitu panelis yang memiliki penebalan di pergelangan kaki dengan diameter \pm 2 $\mathrm{cm}$ [7], sebelum menggunakan krim diukur diameter awal penebalan kulit masing-masing panelis.

Cara pemakaian sediaan krim yaitu bagian kulit menebal dicuci dahulu lalu dikeringkan, dioleskan krim secukupnya 3 kali sehari. Plester tahan air digunakan pada saat memakai alas kaki atau bekerja hal ini dilakukan untuk meminimalisir agar krim tidak terhapus. Setelah itu kulit yang terkelupas di gosok dan dibersihkan.Pengobatan dilakukan selama satu bulan atau 30 hari. Pengamatan dilakukan satu kali dalam seminggu untuk melihat efek terapi dari krim papain kasar getah buah pepaya dengan melihat perubahan [8]

\subsection{Analisis Data}

Data yang diperoleh berupa data diameter penyembuhan kulit callus disajikan secara deskriptif dalam bentuk tabel.

\section{Hasil dan Pembahasan}

Penelitian ini melihat aktivitas papain kasar getah buah pepaya dalam bentuk sediaan krim. Papain yang terdapat dalam getah buah pepaya memiliki efektivitas proteolitik yang luas terhadap protein, rantai pendek peptida, ester asam amino dan amida dan juga dimanfaatkan secara luas di bidang makanan dan obat-obatan [2]. Enzim papain memiliki efektivitas menghidrolisis ikatan peptida menjadi molekul yang lebih sederhana yaitu asam amino. Hal ini yang dimanfaatkan dalam mengatasi penebalan kulit (Callus) [3].

Papain kasar diperoleh dengan cara menyadap dipagi hari, hal ini dilakukan untuk menjaga kondisi kelembapan lingkungan tetap tinggi, apabila kelembapan relatif lingkungan tinggi maka kecepatan alir getah akan tinggi juga (Iswanto, K.H, $\mathrm{dkk}, 2010)$. Lalu disimpan didalam wadah stainles stell dan ditambahkan antioksidan yaitu natrium metabisulfit $2,8 \%$ dari jumlah getah dengan tujuan untuk mempertahankan efektivitas proteolitik.

Papain kasar dikeringkan dengan metode pengeringan beku (freeze drying). Berdasarkan hasil penelitian terdahulu diperoleh kadar protein papain kasar yang tertinggi dengan metode pengeringan beku sebesar 14,19\% [9]. hal ini karena mekanisme pengeringan beku tidak menggunakan pemanasan, sehingga kandungan protein yang terkandung dapat dipertahankan. Bahan yang dikeringkan terlebih dahulu dibekukan dilanjutkan dengan pengeringan menggunakan tekanan rendah sehingga kandungan air yang sudah menjadi es akan langsung menjadi uap, dikenal dengan istilah sublimasi [10].

Basis krim yang digunakan dalam penelitian ini adalah basis krim air dalam minyak (A/M). Tidak menggunakan dasar krim minyak dalam air yang memiliki kandungan air lebih besar. Hal ini karena papain rusak dapat rusak dengan adanya air (Iswanto, K.H, dkk, 2010). Konsentrasi papain yang digunakan yaitu $10 \%, 15 \%, 20 \%$. Pemilihan konsentrasi ini didasarkan pada peneliti terdahulu yang telah melakukan uji efektifitas krim papain untuk pengobatan tumit pecah-pecah [11]. Komposisi basis krim terdiri dari asam stearat, trietanolamin, cera alba, cetaceum digunakan sebagai zat pengemulsi, gliserin sebagai zat humektan untuk menjaga kelembapan kulit, nipagin dan nipasol sebagai bahan pengawet. Penggunaan bahan-bahan tersebut dapat menghasilkan sediaan krim dari papain kasar getah pepaya atau papain untuk pengobatan penyakit callus yang stabil secara fisika dan kimia serta dapat mempertahankan efektifitas yang optimal dalam jangka waktu tertentu. 
Tabel 3. Uji Efektivitas Krim Papain

\begin{tabular}{lcccccc}
\hline \multirow{2}{*}{ Formula } & \multicolumn{9}{c}{ Diameter penebalan kulit (cm) pada minggu ke- } & \multirow{2}{*}{$\begin{array}{c}\text { Pengurangan } \\
\text { Diameter (cm) }\end{array}$} \\
\cline { 2 - 5 } & $\mathbf{0}$ & I & II & III & IV & \\
\hline Kontrol (+) & 2,05 & 1,75 & 1,5 & 1,25 & 0,7 & 1,35 \\
Kontrol (-) & 2,8 & 2,8 & 2,8 & 2,8 & 2,8 & 0 \\
Formula I & & & & & & 0,65 \\
Panelis A & 2,4 & 2,4 & 2,05 & 1,8 & 1,75 & 0,65 \\
Panelis B & 2,75 & 2,55 & 2,5 & 2,35 & 2,1 & 0,35 \\
Panelis C & 2,35 & 2,05 & 2,25 & 2,05 & 2,0 & \\
Rata-rata FI & & & & & & \\
& & & & & & \\
Formula II & 2,0 & 1,85 & 1,65 & 1,65 & 1,6 & \\
Panelis A & 2,1 & 1,95 & 1,6 & 1,5 & 1,5 & \\
Panelis B & 2,15 & 2,05 & 1,7 & 1,7 & 1,55 & \\
Panelis C & & & & & & \\
Rata-rata FII & & & & & & \\
Formula III & 2,65 & 2,25 & 1,85 & 1,7 & 1,4 & \\
Panelis A & 2,3 & 2,2 & 2,05 & 1,85 & 1,8 & \\
Panelis B & 2,4 & 2,25 & 1,95 & 1,75 & 1,7 & \\
Panelis C & & & & & & \\
Rata-rata FIII & & & & & & \\
\hline
\end{tabular}

Tabel 4. Hasil Evaluasi pH Krim Papain

\begin{tabular}{lcccccccc}
\hline & \multicolumn{8}{c}{ pH Sediaan pada minggu ke- } \\
\cline { 2 - 9 } & I & II & III & IV & V & VI & VII & VIII \\
\hline Formula I & 6,4 & 6,5 & 6,5 & 6,5 & 6,5 & 6,6 & 6,9 & 6,5 \\
Formula II & 6,4 & 6,9 & 6,7 & 6,6 & 6,4 & 6,8 & 6,7 & 6,4 \\
Formula III & 6,4 & 6,7 & 6,6 & 6,6 & 6,5 & 6,7 & 6,7 & 6,9 \\
\hline
\end{tabular}

Semua formula krim papain menunjukkan organoleptis berbentuk semi padat berminyak, berbau khas, dan bewarna putih (Gambar 1). Krim stabil selama 8 minggu penyimpanan yang ditunjukan dengan tidak terjadi perubahan bentuk, bau dan warna. Krim yang dihasilkan menunjukkan susunan yang homogen.

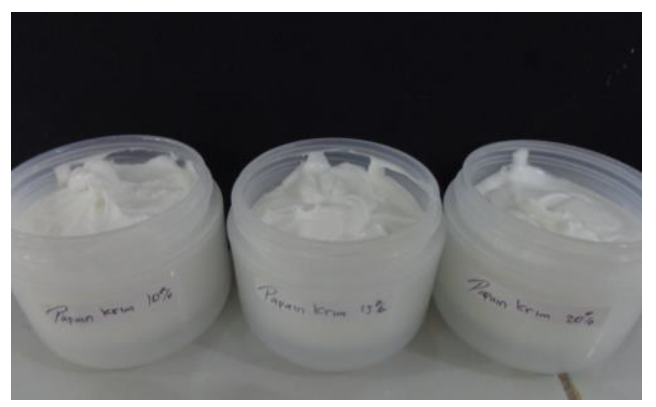

Gambar 1. Organoleptis Formula Krim Papain
Zat aktif papain kasar getah buah pepaya dengan basis dapat tercampur rata dan tidak terlihat butiranbutiran bila krim dioleskan pada sekeping kaca transparan. $\mathrm{pH}$ sediaan krim papain kasar getah buah pepaya selama 8 minggu penyimpanan masing-masing formula menunjukkan penurunan dan peningkatan $\mathrm{pH}$ seperti yang terlihat pada Tabel 4. Range $\mathrm{pH}$ kulit yaitu 4,5-6,5, sedangkan data yang diperoleh menunjukkan nilai $\mathrm{pH}$ 6,3-6,9. $\mathrm{pH}$ papain kasar getah buah pepaya yaitu 5,4, ini dipengaruhi dari kandungan protease pada papain kasar yang mempunyai sifat aktif dalam suasana asam, netral dan alkalis. Oleh karena itu maka sediaan krim papain kasar getah buah pepaya perlu dilakukan uji iritasi terlebih dahulu.

Uji iritasi dimaksudkan untuk mengetahui apakah sediaan uji tersebut dapat menyebabkan reaksi iritasi kulit atau tidak. Uji iritasi kulit sediaan krim papain kasar getah buah pepaya dilakukan dengan uji tempel pada 15 orang panelis, dimana 5 orang panelis mewakili 1 formula sediaan 3 orang laki-laki dan 2 
orang perempuan (Tabel 5). Uji ini dilakukan dengan menempelkan sediaan krim pada lengan bagian dalam selama 24 jam. Dari hasil uji iritasi kulit terhadap 15 orang panelis menunjukkan tidak adanya iritasi, walaupun $\mathrm{pH}$ krim papain kasar getah buah pepaya melebihi dari range $\mathrm{pH}$ kulit. Hal ini karena pada kulit terjadi sistem pertahanan yaitu proses deskuamasi yang merupakan proses terlepasnya startum korneum dan akan digantikan dengan kulit yang baru [12].

Tabel 5 : Hasil Uji Iritasi Krim Papain

\begin{tabular}{ccccccc}
\hline No & Formula & \multicolumn{5}{c}{ Panelis } \\
\cline { 3 - 7 } & & $\mathbf{1}$ & $\mathbf{2}$ & $\mathbf{3}$ & $\mathbf{4}$ & $\mathbf{5}$ \\
\hline 1 & FI & TI & TI & TI & TI & TI \\
2 & FII & TI & TI & TI & TI & TI \\
3 & FIII & TI & TI & TI & TI & TI \\
\hline
\end{tabular}

Keterangan :

TI : Tidak Iritasi

Uji stabilitas fisik krim pada suhu dingin $\left(0-4^{\circ} \mathrm{C}\right)$ dan suhu kamar bertujuan untuk mengetahui kestabilan fisik sediaan krim terhadap perubahan suhu. Dari hasil evaluasi yang dilakukan selama 8 minggu diperoleh hasil bahwa semua formula tidak terjadi pemisahan, ini menunjukkan bahwa semua formula krim getah buah pepaya stabil.

Pemeriksaan daya tercuci krim papain kasar getah buah pepaya bertujuan untuk melihat mudah atau sukarnya krim tercuci oleh sejumlah air. Krim kategori mudah dtercuci apabila dibutuhkan lebih sedikit air untuk menghilangkan sisa krim. Data hasil uji daya tercuci menunjukkan formula I mudah tercuci dibandingkan formula II dan III (tabel 6 )

Tabel 6. Uji Daya Tercuci Krim Papain kasar Getah buah Pepaya

\begin{tabular}{lc}
\hline \multicolumn{1}{c}{ Formula } & Volume air rata-rata $(\mathbf{m l})$ \\
\hline Formula I & 18 \\
Formula II & 20,5 \\
Formula III & 24.5 \\
\hline
\end{tabular}

Pemeriksaan daya menyebar bertujuan untuk mengetahui apakah krim mudah menyebar ketika dioleskan pada kulit yang sebanding dengan gaya yang dibutuhkan untuk krim dapat menyebar. Prinsip metoda ini adalah krim mudah menyebar bila beban yang dibutuhkan lebih sedikit tetapi membentuk pertambahan luas penyebaran yang lebih besar. Pemeriksaan seharusnya dilakukan dengan menggunakan alat penetrometer, tetapi karena keterbatasan alat maka pemeriksaan dilakukan secara manual dengan prinsip menghitung pertambahan luas yang diberikan oleh sediaan dalam waktu tertentu apabila diberi beban dengan berat tertentu pula [13]. Pada tabel 7 terlihat dengan adanya penambahan beban, diameter penyebaran juga semakin luas. Dapat dilihat juga bahwa diameter penyebaran untuk setiap formula berbeda, semakin tinggi konsentrasi papain kasar getah buah pepaya maka makin luas penyebaran.

Tabel 7. Evaluasi Uji daya Sebar Krim Papain

\begin{tabular}{ccccc}
\hline \multirow{2}{*}{ No } & \multirow{2}{*}{ Beban $(\mathbf{g})$} & \multicolumn{3}{c}{ Luas daya sebar $(\mathbf{c m} 2)$} \\
\cline { 2 - 5 } & & FI & FII & FIII \\
\hline 1 & 10 & 1,42 & 3,95 & 4,79 \\
2 & 20 & 2,94 & 5,65 & 6,22 \\
3 & 30 & 5,58 & 7,44 & 8,10 \\
\hline
\end{tabular}

Metoda yang digunakan penentuan efektivitas krim papain adalah pengukuran diameter awal penebalan kulit dan melihat pengurangan diameter penebalan kulit setelah menggunakan krim papain selama 30 hari. Hasil pada tabel 3 menunjukkan terjadi pengurangan diameter penebalan kulit yang lebih besar pada krim dengan konsentrasi papain yang paling tinggi (20\%). Bila dibandingkan dengan kontrol negatif, krim papain menunjukkan efektivitas, namun bila dibandingkan dengan kontrol positif krim asam salisilat $20 \%$ menunjukkan jumlah pengurangan diameter penebalan kulit yang belum sebanding hal ini karena mekanisme kerja yang berbeda dari papain dan asam salisilat, dimana asam salisilat bekerja dengan cara meningkatkan kelembapan kulit dan mempermudah proses pengelupasan sel kulit mati, sedangkan papain bekerja dengan cara menguraikan protein keratin yang abnormal pada kulit yang menebal [3]. Disamping itu faktor lain yang mempengaruhi adalah pemakaian krim papain kasar getah buah pepaya selama 30 hari belum maksimal dalam menghilangkan penebalan kulit.

\section{Kesimpulan}

Krim papain dari getah buah pepaya dapat diformulasikan dalam bentuk krim air dalam minyak dan menghasilkan krim yang stabil serta tidak berubah selama 8 minggu penyimpanan. Krim papain konsentrasi $10 \%, 15 \%$ dan $20 \%$ dapat mengurangi diameter penebalan kulit pada pergelangan tangan dan kaki, tetapi pengurangan diameter penebalan kulit lebih kecil bila dibandimgkan dengan kontrol positif krim asam salisilat (20\%).

\section{Ucapan Terima Kasih}

Ucapan terima kasih kepada Sekolah Tinggi Ilmu Farmasi Riau atas dukungan dan bantuan dalam pelaksanaan penelitian ini. 


\section{Daftar Pustaka}

1. Rukmana R. Pepaya, Budidaya \& Pasca Panen, Jakarta, Penerbit Kanisius, 1994

2. Amri E, Mamboya F,. (Papain A Plant Enzyme of Biological Importance), American Journal of Biochemistry and Biotechnology., 2012; 8(2), 99-104,

3. Claudinéia A.S.O. Pinto, Green D, André R. Baby ,Gabriele W. Ruas, Telma M. Kaneko, Sandro R. Marana, Maria V.R. Velasco., (Determination of Papain Activity in Topical Dosage Forms) Latin American Journal of Pharmacy, 2007; 26 (5): 771-5.

4. Ercan K, Zafer Kucukodaci,Ersin Aydin, Kursat Goker, Ozlem and Karabudak Abuaf, 2012, A Rare Case Report: Unilateral Punctate Palmoplantar Keratoderma, Presented in Izmir 7.Ege Dermatoloji Gunleri 09-13.

5. Novilasari, Karakterisasi Papain Kasar Dari Buah Pepaya (Carica papaya L) Yang Diperoleh Dengan Teknik Pengering Beku (Freeze drying), Skripsi, 2009, Sekolah Tinggi Ilmu Farmasi Riau
6. Muhidin D. Agroindustri Papain dan Pektin, Jakarta, Penerbit Swadaya, 2004

7. Lu, F.C. Toksikologi Dasar, Jakarta, UI Press, Edisi 2, 1995

8. Sulistyaningrum S.K, Evita H. E, Hanny N, Penggunaan Asam Salisilat Dalam Dermatologi, J Indon Med Assoc 2011: Vol 62 No 7 hal 277.

9. Deivy,A. P., Ikhwan A, dan Isman, (Aktivitas Proteolitik Papain kasar Getah Buah Pepaya Dengan Berbagai Metode Pengeringan), Jurnal Teknologi Pertanian Andalas ; 20 (2) 58-64

10. Muchtadi D, Fisiologi Pasca Panen Sayuran dan Buah-buahan, Bogor, IPB Press, 1992

11. Salman, Ilyas A, Zarmawati., Uji Efektifitas Krim Papain Untuk Pengobatan Tumit PecahPecah, Proseding Seminar Nasional ISFI, 2004 Padang.

12. Lorraine M.W. dan Sylvia A.P. Patofisiologi, Jakarta, Penerbit Buku Kedokteran EGC, 2005

13. Voigt R., Buku Pelajaran Teknologi Farmasi, Yogyakarta, Gadjah Mada University Press, Edisi V, 1994

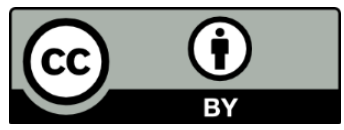

(C) 2020 by the authors; This article is an open access article distributed under the terms and conditions of the Creative Commons Attribution License (http://creativecommons.org/licenses/by/4.0/) 